\title{
IMPROVING THE
}

\section{TRANSLATION-INTERPRETING CURRICULUM THROUGH ACKNOWLEDGING THE EDUCATIONAL NEEDS OF ALBANIAN STUDENTS}

\author{
Mirela Papa \\ University of Tirana, Albania \\ E-mail: papamirela@yahoo.com \\ Alma Hafizi \\ University of Shkodra, Albania \\ E-mail: almahafizi@yahoo.it
}

\begin{abstract}
The introduction of the Bologna Process into the higher education system in Albania has led to a review and improvement of the existing curricula.

Among the variables influencing the curriculum development the professors and students are the ones directly involved in the curriculum reform implementation project.

Although the Bologna Charter advocates a student-centred approach, students are not given the priority they deserve. This remiss could lead to a conflict between the students' expectations and the curricular approaches.

First and second year Master students of Translation - Interpreting at the University of Tirana are the subject of a survey aiming at finding out how the students undertaking Translation and Interpreting find the courses they follow. The method used is the quantitative method of observation. $80 \%$ of the students have filled in a questionnaire.

The data processing indicates the motives driving the students to choose this curriculum as well as their expectations for their future career.

It is concluded with some findings and recommendations for curriculum reform, since the academic offer is seen as a means of providing answers for a society which, under the pressure of ongoing changes, is in need of professionals who respond to new stimuli.
\end{abstract}

Key words: curriculum, expectations, interpreting, motivations, translation.

\section{Introduction}

The early forerunners of the curriculum date back to Plato's epoch (Flinders and Thornton, 2004). The curriculum entails various aspects of many other disciplines such as history, anthropology, sociology, economics, psychology and methodology (Diaz Barriga, 2003). García Pascual (2004) draws a distinction between methodology which gives priority to the how of education (activities, methods, teacher - student relationship, evaluation) and the curriculum which focuses on the what (contents, syllabus and the people involved in it, a culture that is sought to be conveyed, objectives, educational purposes, education context, the epistemological justification for education etc.)

There are three main historical stages in the development of the curriculum theory 
PROBLEMS

OF EDUCATION

IN THE $21^{\text {st }}$ CENTURY

Volume 43, 2012

70

(Bolívar, 1999). All epochs are characterized by objectives, educational purposes, because as Bolívar explains (2008) the teaching process or education is always a purposeful activity. Denying this is denying the meaning of education itself. Not all the purposes are alike. What has changed is the way these purposes are conceptualized in order to ensure that they reflect the current trends and this has resulted in different curricular proposals in different epochs.

The first stage (1920-1950) witnessed the rational planning model: the product. Both Bobbit and Tyler (representatives of this stage) based their theories on the concept of conductive teaching objectives.

During the second stage (1960-1975) it was the practical approach which prevailed: the process. Stenhouse states that it is not enough to plan teaching from an abstract and simple rational perspective. It is necessary to take into account the class reality as well as the educational situation reality in general (1970). Schwab, too, insists on taking into account the students', professors' and experts' viewpoints when making decisions about the curriculum. (Schwab, 1969)

During the third stage (1975-1990) it was the critical theory which emerged. This period is characterised by a reconceptualization of the curriculum and the domination of the technical approach starts to be defied. The teacher's role is now considered a key role (Bolívar, 1999).

After the '90s, in the framework of the European Union, The White Book on Education and Training: towards a cognitive society (1995) underlines the fact that our society is undergoing radical changes, which is a result of the emergence of the Information Society, globalism and the scientific and technical revolution. The education plan enables the selection of the learning competencies and outcomes that will respond to this new reality. According to the World Declaration on higher education in the $21^{\text {st }}$ century: Vision and Action approved by UNESCO (1998) the information society means the accumulation of knowledge in a non-functional way leads to a loss of its meaning, while the skill to locate, process, analyze, enquire, question, implement and add to the information available at a given context needs to be reinforced.

Along the same lines as the purposes of UNESCO, the Bologna Declaration (1999) restructures higher education to conform to the 3 cycle model (Bachelor, Master and Doctorate) in all the countries of European Higher Education Area and chooses the competencies as a common system to structure these reforms based on some criteria of comparability in all the participating countries. The competencies are applied in two main directions: 1) separation from vocational qualifications and the way to link the market - society with the education programs. 2 ) as a return to the student- oriented education practice with an innovative teaching notion.

The European Union paper regarding the purposes and competences of higher education reads: Broadly speaking, one may identify four main purposes of higher education: preparation for the labour market; preparation for life as active citizens in a democratic society; personal development; the development and maintenance of a broad, advanced knowledge base (BFUG, 2004)

The curricula in all the European countries were changed to comply with the Bologna Declaration. The agents involved in the development of a university curriculum are: the national Administration, European Administration, labour market agents and social agents as well as professors and students who are directly involved in the implementation of a curricular project. There is no doubt as to what the European aim is: a student-focused model (Sanz, 2003). The World Declaration on Higher Education in the $21^{\text {st }}$ Century (1998) states that the national and institutional syllabus drafters should focus on students and their needs.

\section{Problems of the Research}

The Bologna Charter was implemented for the first time in Albania during the academic year 2005-2006. The introduction of the Bologna system to the Foreign Language Faculty 
brought changes to the existing curricula. The Translation - Interpreting curriculum, which was in place even during the old 4-year school system, was revised and enriched to meet the market demands as well as to adapt to similar curricula in other western countries. Thus, through the old curriculum students acquired translation and interpreting knowledge and skills in only 2 languages, namely the mother tongue, called language $\mathrm{A}$, and in the first foreign language called language $B$. Language $C$ was introduced into the new curriculum for the 2-year cycle as is the practice in other European countries as well, because our context is no stranger to the models which are created outside our borders but in the same globalized world we all live in.

This study aims to find out how Translation - Interpreting students feel about their studies, what the reasons behind their choice of a career in translation and interpreting is, what their expectations of the study program undertaken are, the professional aspects of their future jobs as well as what their evaluation of the education they have received is. It provides some findings and recommendations for the improvement of the curriculum.

\section{Methodology of Research}

\section{General Background of Research}

The best way to find the explanations, identify the clues and phenomena that form the basis of the analysis of a curriculum, as the students perceive it, was considered to be the descriptive investigation which, according to some authors, may be included in the ethnographic investigations (Nunan, 1992). There are no studies in Albania to link together the students' concepts, identity and curricular experience in Translation - Interpreting for the time being. Neither have the students' behaviour and perceptions concerning their career ever been studied. This study seeks a clear approach to a macroconcept called the student's identity. This empirical study finds common ground with other studies on the Translation - Interpreting curriculum carried out in other countries like Poland (Kearns, 2006), Germany (Nord, 2005a), Hong-Kong (Li, 2002) etc., although the curricular contexts and framework are completely different.

\section{Sample of Research}

The target students of this study are the 2-year Master program students of Translation and Interpreting at the Faculty of Foreign Languages, University of Tirana. The sample of students consists of first and second year students. 132 students (59 first year students and 73 second year students) were involved in this study which, from the point of view of the sample volume, makes a satisfactory percentage, since it is approximately $80 \%$ of a total of 166 enrolled students (70 in the first year and 96 in the second year).

A questionnaire was used to collect data. The questionnaire questions were closed-ended questions so as to make it easier to collect and process the outcomes data. Some of the questions were open-ended so as to make it possible for the students to give spontaneous answers in order to gather new interesting data for the study. This method was selected for the following reasons: 1) it enables collecting answers about many topics in a short period of time (Brennan and Williams, 2004). 2) It provides access to a great number of individuals 3) quatificable outputs.

\section{Instrument and Procedures}

As many authors state, there is not only one general methodological perspective in an investigation, but it is necessary that the steps to be followed in order to guarantee a solid methodology reflect the contexts and meet the objectives of any investigation (Fink, 1995; Oppenheim, 1992). The study refers to the study methodology of Grotjahn (1987). He makes 
PROBLEMS

OF EDUCATION

IN THE $21^{\text {st }}$ CENTURY

Volume 43, 2012

an in-depth analysis of the applied methodology in the study of language. The study follows the mixed exploratory - quantitative-interpretative model of Grotjahn and it is a non-experimental study. There is no inspection group, no controlled empirical manipulation.

The data collected through the questionnaire have a quantitative nature. The study has gathered quantitative data regarding different aspects of the student's identity such as: 1) the student's profile 2) preferences 3) background information on career 4) motives 5) expectations 6) the evaluation of the received education.

The data has been gathered and shown in separate tables which have made it possible to offer an interpretation of the results yielded as well.

\section{Data Analysis}

The questionnaires were completed by the students in classrooms where the authors of this study were present. In terms of the time allowed, they were given all the time needed as specified by Brennan and Williams (2004). Cooperation and understanding of the professors was sought to use a part of their class time so the students could complete the questionnaire. This particular method was chosen as a very effective one (Kumar, 1996) for the collective administration of the questionnaires which makes it possible to avoid outside influence on individual answers and to remove any doubts the respondents might have concerning certain questions. The questionnaire was conducted in April 2012. It was completed by 132 students. Of all the students who completed the questionnaire 17 were male and 115 female students.

To enter the data the first step was creating classification tables in which different categories of possible answers were grouped. And since the questionnaire was neither digital nor electronic the data was entered manually. To minimize human errors in this process, all the data analyzed was first entered into the tables printed on paper and then into the computer. Both data transfer processes were double-checked to continue with calculating the percentage of the given answers. The majority of the variables included in this analysis were variables independent of the subject, due to the non-experimental and descriptive nature of the study. Being independent variables they were not subject to manipulation which is why the findings were entered in terms of frequency. The descriptive method and the frequency analysis was the one used for the first 15 tables, whereas the last table which provides the results in connection with the evaluation students give for the received education was assessed according to Likert scale ranging from 1 (fully disagree) to 3 (fully agree).

\section{Results of Research}

The questionnaire served to collect data about the respondent students. The following are the results about each of the above-mentioned aspects which constitute the basis of this study.

\section{The student's profile}

Tables 1-4 provide data concerning the profile of the students undertaking Translation - Interpreting studies: the students' age, previous studies, work experiences, if they have had any. 
Mirela PAPA, Alma HAFIZI. Improving the Translation-Interpreting Curriculum through Acknowledging the Educational Needs of Albanian Students

Table 1. The respondents' age.

\begin{tabular}{|c|c|c|}
\hline The respondents' age & Absolute value & Percent, $\%$ \\
\hline $21-23$ & 93 & 70.45 \\
\hline $24-26$ & 22 & 16.67 \\
\hline $27-29$ & 2 & 1.52 \\
\hline No answer & 15 & 11.36 \\
\hline Total & 132 & 100 \\
\hline
\end{tabular}

Based on the data gathered on the respondents' age $70.45 \%$ of the students belong to the $21-23$ age group; $16.67 \%$ of the students belong to the $24-26$ age group; whereas $1.52 \%$ of the respondent students belong to the 27-29 age group.

Table 2. The type of first cycle studies.

\begin{tabular}{|l|l|c|c|}
\hline \multicolumn{2}{|c|}{ First cycle studies } & Absolute value & Percent, \% \\
\hline \multirow{3}{*}{$\begin{array}{l}\text { The Bologna } \\
\text { System } \\
(3+2)\end{array}$} & Language, Literature, Civilisation curriculum & 29 & 21.97 \\
\cline { 2 - 4 } & Translation - Interpreting curriculum & 76 & 57.58 \\
\cline { 2 - 4 } & Language - Communication Curriculum & 6 & 4.55 \\
\cline { 2 - 4 } & British - American Studies Curriculum & 11 & 8.33 \\
\hline \multirow{4}{*}{$\begin{array}{l}4 \text { years } \\
\text { System }\end{array}$} & Language Teaching Curriculum & 8 & 6.06 \\
\cline { 2 - 4 } & Translation - Interpreting Curriculum & 2 & 1.51 \\
\cline { 2 - 4 } & British- American Studies Curriculum & - & - \\
\hline \multirow{2}{*}{ No answers } & & - & - \\
\hline \multirow{2}{*}{ Total } & \multirow{2}{*}{132} & 100 \\
\hline
\end{tabular}

In the table above the students are grouped based on the studies they have undertaken in their first cycle of studies. $7.57 \%$ of the students from the old 4-year system have undertaken the Translation - Interpreting study program. The rest comes from the new Bologna system. The majority of the latter (57.58\%) studied Translation - Interpreting in the 3-year cycle. The other significant percentage 21.97 studied Language, Literature and Civilisation. $8.33 \%$ of the students studied British Studies in the first cycle of studies and $4.55 \%$ of them come from the other first cycle of studies curriculum which is Language-Communication.

Table 3. Background qualifications considered important for the study program.

\begin{tabular}{|l|l|c|c|}
\hline \multicolumn{2}{|c|}{ Background qualifications } & Absolute value & Percent, $\%$ \\
\hline \multirow{3}{*}{ Yes } & Taking a course in the language B country & 24 & 18.18 \\
\cline { 2 - 4 } & Staying for a long period of time in the language B country & 4 & 3.03 \\
\cline { 2 - 4 } & Studying in the language B country & 2 & 1.515 \\
\hline No & No answers & 100 & 75.76 \\
\hline \multicolumn{2}{|l|}{ Total } & 2 & 1.515 \\
\hline
\end{tabular}


PROBLEMS

OF EDUCATION

IN THE $21^{\text {st }}$ CENTURY

Volume 43,2012

Concerning the background qualification that the students consider important for their study program $75.76 \%$ of the respondent students state that they did not have any background qualification they would consider important for their studies. $18.18 \%$ of them are of the opinion that a language course in the language B country has contributed to their development; 3.03\% are of the opinion that living for many years in the language B country has helped them; whereas a very small percentage studied in the language B country and this has positively affected their development.

Table 4. Work experience.

\begin{tabular}{|l|l|c|c|}
\hline \multicolumn{2}{|c|}{ Work experience } & Absolute value & Percent, \% \\
\hline \multirow{3}{*}{ Yes } & Call çętrẹ operators & 37 & 28.03 \\
\cline { 2 - 4 } & Foreign language teachers at private courses & 26 & 19.7 \\
\cline { 2 - 4 } & Translators & 21 & 15.91 \\
\hline & Miscellaneous jobs & 5 & 3.79 \\
\hline No & & 43 & 32.57 \\
\hline \multirow{2}{*}{ No answers } & - & - \\
\hline \multicolumn{2}{|l|}{ Total } & 132 & 100 \\
\hline
\end{tabular}

Table 4 shows the students' experience of the world of work. There are approximately $1 / 3$ or exactly $32.57 \%$ of the students who have had no work experience, whereas the rest $64.43 \%$ have had work experiences, even though the majority of them $28.03 \%$ have worked or still work as call centre operators. The fact that a considerable number of students have worked or work as teachers of foreign languages or translators, $19.7 \%$ and $15.91 \%$ respectively, is a positive thing. $3.79 \%$ of the students undertaking this curriculum have done or do different jobs.

\section{Preferences}

Tables 5 and 6 display data collected in connection with the students' preferences at the moment of deciding on the field of study in the second cycle of studies. This is important to identify the motives behind the students' choice to undertake Translation- Interpreting.

Table 5. Translation - Interpreting as the first choice when applying for the second cycle of studies.

\begin{tabular}{|c|c|c|}
\hline Translation -Interpreting as the first choice & Absolute value & Percent, $\%$ \\
\hline Yes & 126 & 95.45 \\
\hline No & 3 & 2.275 \\
\hline No answers & 3 & 2.275 \\
\hline Total & 132 & 100 \\
\hline
\end{tabular}

$95.45 \%$ of the students gave a positive answer to the question of whether or not Translation - Interpreting was their first choice when they applied for the second cycle of studies. The curriculum in question was not the first choice for only $2.275 \%$ of the students, whereas $2.275 \%$ of the students did not answer the question. 
Mirela PAPA, Alma HAFIZI. Improving the Translation-Interpreting Curriculum through Acknowledging the Educational Needs of Albanian Students

Table 6. Applications for other study programs offered by the Faculty.

\begin{tabular}{|c|c|c|}
\hline Applications for other study programs offered & Absolute value & Percent, \% \\
\hline Yes & 38 & 28.79 \\
\hline No & 94 & 71.21 \\
\hline No answer & - & - \\
\hline Total & 132 & 100 \\
\hline
\end{tabular}

As Table 6 shows, the students have answered the question whether or not they applied for other study programs offered by the faculty. The answers show that for $71.21 \%$ of them Translation - Interpreting was their first and only preference, whereas $28.79 \%$ of the students had applied for other curricula offered by the faculty in addition to Translation -Interpreting.

\section{Preliminary Information on Career}

Tables 7-11 display data in connection with the preliminary information that the Translation - Interpreting students had available at the moment they decided which study program to undertake in their second cycle of studies.

Table 7. Orientation to possible study programs and career.

\begin{tabular}{|c|c|c|}
\hline Orientation to possible study programs and career & Absolute value & Percent, $\%$ \\
\hline Yes & 90 & 68.18 \\
\hline No & 42 & 31.82 \\
\hline No answers & - & - \\
\hline Total & 132 & 100 \\
\hline
\end{tabular}

Table 7 presents data in connection with the question of whether or not the students were offered the proper orientation at the faculty to the studies they wanted to pursue and career. The majority of the students $68.18 \%$ state they had received orientation at the faculty, but the percentage of those students who state that they had not received the proper orientation from the faculty at the moment they decided which curriculum to choose for their studies is not small, either $(31.82 \%)$.

Table 8. Orientation to careers in translation and interpreting.

\begin{tabular}{|l|l|c|c|}
\hline \multicolumn{2}{|c|}{ Orientation to careers in translation and interpreting } & $\begin{array}{c}\text { Absolute } \\
\text { value }\end{array}$ & $\begin{array}{c}\text { Percent, } \\
\%\end{array}$ \\
\hline \multirow{4}{*}{ Yes } & $\begin{array}{l}\text { Orientation to the criteria to be met for admission to the Translation } \\
\text { - Interpreting Master program }\end{array}$ & 70 & 53.03 \\
\cline { 2 - 4 } & Information on the subjects to be covered & 10 & 7.58 \\
\cline { 2 - 4 } & Other information & & \\
\hline No & & 52 & 39.39 \\
\hline No answers & -132 & - \\
\hline Totally & & 100 \\
\hline
\end{tabular}


PROBLEMS

OF EDUCATION

IN THE $21^{\text {st }}$ CENTURY

Volume 43,2012

$39.39 \%$ of the students state that they had not had the proper orientation to careers in translation and interpreting. Even among the students stating they received the right orientation to these careers only $7.58 \%$ of them had received information about the subjects to be covered which is the most important information a student needs to have in order to have a clear idea about the course he is going to follow and the best career prospects this course will offer. While the majority of the students $53.03 \%$ had only received information about the criteria to be met in order to be admitted to the Translation - Interpreting study program.

Table 9. Other sources of information on Translation - Interpreting studies.

\begin{tabular}{|l|l|c|c|}
\hline \multicolumn{2}{|c|}{ Other Information about the study program } & Absolute value & Percent, \% \\
\hline \multirow{4}{*}{\begin{tabular}{l} 
Yes (indi- $\begin{array}{l}\text { cate the } \\
\text { source) }\end{array}$ \\
\cline { 2 - 4 }
\end{tabular}} & Internet & 13 & 9.85 \\
\cline { 2 - 4 } & Former Translation - Interpreting students & 45 & 34.09 \\
\cline { 2 - 4 } & Translators, interpreters & 9 & 6.82 \\
\cline { 2 - 4 } & Friends, family & 10 & 7.57 \\
\cline { 2 - 4 } & Other sources & & \\
\hline No & & 55 & 41.67 \\
\hline No answer & & 132 & \\
\hline Total & & 100 \\
\hline
\end{tabular}

Table 9 refers to the question of whether or not the respondent students had received information about their studies from sources other than the faculty and if so they were supposed to indicate these sources. $41.67 \%$ of the students had not received any information other than the one from the faculty; $34.09 \%$ of the students had gathered information from former students of the same study program. $9.85 \%$ of the students state that they had received additional information from the internet in connection with the Translation - Interpreting curriculum. Friends and family had given their contribution to $7.57 \%$ with the information they possessed, whereas $6.82 \%$ of the students had received the information from professional translators and interpreters.

Table 10. The adequate information before the Translation - Interpreting studies began.

\begin{tabular}{|c|c|c|c|}
\hline \multicolumn{2}{|c|}{ The adequate or inadequate information before the start of the studies } & \multirow{2}{*}{$\begin{array}{c}\text { Absolute } \\
\text { value } \\
65\end{array}$} & \multirow{2}{*}{$\begin{array}{c}\text { Percent, \% } \\
49.24\end{array}$} \\
\hline Yes & & & \\
\hline \multirow{3}{*}{$\begin{array}{l}\text { No (what was } \\
\text { missing?) }\end{array}$} & Unspecific & 21 & 15.91 \\
\hline & $\begin{array}{l}\text { Subjects included in the curriculum, employment possibilities } \\
\text { offered with such qualification, translators and interpreters' } \\
\text { pay etc. }\end{array}$ & 38 & 28.79 \\
\hline & Information on interpreting as a subject & 8 & 6.06 \\
\hline \multicolumn{2}{|l|}{ No answers } & - & - \\
\hline \multicolumn{2}{|l|}{ Total } & 132 & 100 \\
\hline
\end{tabular}

Table 10 presents data gathered from the answers to the question of whether the students asked thought they had the proper information before they started their Translation - Interpreting studies. This was one of the open -ended questions of the questionnaire. If the information was 
the proper one the students were supposed to give a positive answer, but if they thought they had not been given the proper information they had to specify what was missing. Less than half of the students $49.24 \%$ think they were given the proper information. The rest answered negatively to the question. As regards the information they think was missing $28.79 \%$ of the students say that they were not given any information about the subjects they were going to study, they did not know what their employment opportunities were with such qualification, how much they were going to be paid in the future etc., whereas a small percentage $6.06 \%$ of the students state that they did not have the proper information about interpreting as a subject. $15.91 \%$ of the students think they were not given the proper information, but without specifying what information they wished they had been given.

Table 11. The proper information on careers in translation and interpreting.

\begin{tabular}{|l|l|c|c|}
\hline \multicolumn{2}{|l|}{ The proper information or not } & $\begin{array}{c}\text { Absolute } \\
\text { value }\end{array}$ & Percent, \% \\
\hline Yes & & 73 & 55.30 \\
\hline \multirow{2}{*}{$\begin{array}{l}\text { No (what was } \\
\text { missing) }\end{array}$} & Career prospects & 59 & 44.70 \\
\cline { 2 - 4 } & Translators and interpreters' pay & - & - \\
\cline { 2 - 4 } & Translators and interpreters' prestige & - & - \\
\hline No answer & & - & - \\
\hline \multicolumn{2}{|l|}{ Total } & 132 & 100 \\
\hline
\end{tabular}

Table 11 asks students whether they think they have the proper information now after 1 or 2 years of study (depending on the year they are in) regarding the career paths they have chosen to follow. $55.30 \%$ of the students think they now have the proper information about a career in translation and interpreting, whereas $44.70 \%$ of them think they do not possess the proper information about the career prospects they will have upon completion of the study program. The pay and the profession's prestige does not seem to be very important for the students for now bearing in mind that they still wonder where they will be working.

\section{Motivations}

Tables 12 and 13 display the outcomes concerning the motivations that have driven the students to decide on studying Translation - Interpreting in their second cycle of studies as well as the factors that influenced their choice. 
PROBLEMS

OF EDUCATION

IN THE $21^{\text {st }}$ CENTURY

Volume 43, 2012

Table 12. Motivations behind the decision to undertake Translation - Interpreting curriculum.

\begin{tabular}{|c|l|c|c|}
\hline No & Why did you decide to study Translation - Interpreting? & $\begin{array}{c}\text { Absolute } \\
\text { value }\end{array}$ & $\begin{array}{c}\text { Percent, } \\
\%\end{array}$ \\
\hline 1 & Because I like foreign languages & 96 & 72.72 \\
\hline 2 & Because I have a good knowledge of two or more foreign languages & 59 & 44.69 \\
\hline 3 & Because I want to learn more foreign languages throughout my career & 58 & 43.94 \\
\hline 4 & Because I would like to do a job that involves using foreign languages & 83 & 62.87 \\
\hline 5 & Because I like travelling & 56 & 42.42 \\
\hline 6 & Because I like meeting people from other countries & 57 & 43.18 \\
\hline 7 & Because I like the subjects covered by this program & 10 & 7.57 \\
\hline 8 & $\begin{array}{l}\text { Because I would like to facilitate communication between people belonging to } \\
\text { different cultures }\end{array}$ & 53 & 40.15 \\
\hline 9 & Because I find the translator's job very interesting & 79 & 59.84 \\
\hline 10 & Because I find the interpreter's job very interesting & 46 & 34.84 \\
\hline 11 & Because translators and interpreters are well-paid & 49 & 37.12 \\
\hline 12 & Because a career in translation and interpreting is a prestigious one & 45 & 34.09 \\
\hline
\end{tabular}

Table 12 outlines the motives that have driven the students to decide on the Translation - Interpreting curriculum in the second cycle of their studies. The motives could naturally be more than one and that is why the students could circle more than one option.

The first motivation for the majority of the students is definitely "because I like foreign languages". $72.72 \%$ of the students listed this motivation for the choice made. $62.87 \%$ of the students wrote "because I would like to do a job that involves using foreign languages". "Because I find a translator's job very interesting" is the motivation for $59.84 \%$ of the students. $44.69 \%$ of the students say that among reasons for wanting to undertake this curriculum was "because I have a good knowledge of two or more foreign languages". "The desire to meet people from other countries", "the desire to learn more foreign languages during one's career" or "the desire to travel" have influenced the students' choice to the same extent $-43.18 \%, 43.94 \%$ and $42.42 \%$ respectively. Among other reasons influencing the choice made the following may also be listed: "because I would like to facilitate communication between people belonging to different cultures" $-40.15 \%$; "Because translators and interpreters are well-paid" - 37.12\%; "Because I find the interpreter's job very interesting" $-34.84 \%$. The students also think that a career in translation and interpreting enjoys a certain prestige and thus, aspiring to a prestigious career, a relatively high percentage of students (34.09\%) underline it as one of the motivations behind the choice of career. What the students seem to be less interested in is the subjects covered by the program. As a matter of fact, only $7.57 \%$ of them list "I like the subjects covered by this program" among the reasons. 
Table 13. Factors that influenced the decision taken.

\begin{tabular}{|c|l|c|c|}
\hline No. & \multicolumn{1}{|c|}{ Factors that influenced the decision taken } & Absolute value & Percent, \% \\
\hline 1 & $\begin{array}{l}\text { It was recommended by family members or other people who have } \\
\text { nothing to do with translation }\end{array}$ & 12 & 9.09 \\
\hline 2 & $\begin{array}{l}\text { I chose it because I was told it offers good career prospects for the } \\
\text { future }\end{array}$ & 56 & 42.43 \\
\hline 3 & $\begin{array}{l}\text { I chose it because I didn't particularly like the other study programs } \\
\text { offered }\end{array}$ & 40 & 30.30 \\
\hline 4 & I chose it because I don't want to end up a foreign language teacher & 20 & 15.15 \\
\hline 5 & Other motivations & 4 & 3.03 \\
\hline & Total & 132 & 100 \\
\hline
\end{tabular}

Table 13 presents data regarding the factors influencing the students' decision to undertake the Translation - Interpreting studies. If a closer look is taken to the data the reason ranked first (42.43\%) is "I was told it offers good career prospects for the future". The reason ranked second is "I didn't particularly like the other courses of study offered" with $30.30 \%$ of the respondents driven by this very factor. $15.15 \%$ of the students do not want to become foreign language teachers and that is why they decided on the Translation- Interpreting studies as a more reasonable choice compared to the other alternatives. $9.09 \%$ of the students were advised to make this choice by family members or people who have nothing to do with translation. A very small percentage $(3.03 \%)$ of the students were driven by other unspecified reasons.

\section{Expectations}

Tables 14 and 15 provide data about the students' perceptions about their future career, the objective being to gain insight into their idea of the kind of work they will be doing and also what information they have about their future career.

Table 14. What type of work do you think you will be doing upon completion of the studies?

\begin{tabular}{|c|c|c|c|}
\hline No & The job you think you will be doing upon completion of the studies & $\begin{array}{c}\text { Absolute } \\
\text { value }\end{array}$ & $\begin{array}{c}\text { Percent, } \\
\%\end{array}$ \\
\hline 1 & A job that fits the studies pursued, but it seems to be difficult to have & 34 & 25.76 \\
\hline 2 & $\begin{array}{c}\text { Translator (at a publishing house, embassy, foreign affairs ministry, foreign } \\
\text { organizations, private foreign companies etc.) }\end{array}$ & 69 & 52.27 \\
\hline 3 & Interpreter at the Foreign Affairs Ministry, Embassy etc. & 6 & 4.54 \\
\hline 4 & University professor, teacher & 2 & 1.52 \\
\hline 5 & A job that has nothing to do with the study program undertaken & 3 & 2.27 \\
\hline 6 & I don't know & 8 & 6.06 \\
\hline 7 & Go abroad for further qualifications & 2 & 1.52 \\
\hline 8 & Translator/Interpreter with EU institutions & 3 & 2.27 \\
\hline 9 & No answer & 5 & 3.79 \\
\hline & Total & 132 & 100 \\
\hline
\end{tabular}


PROBLEMS

OF EDUCATION

IN THE $21^{\text {st }}$ CENTURY

Volume 43,2012

Table 14 shows how the students answered the question about what kind of work they think they will be doing after the completion of their studies. In order not to compromise the variety of answers this question was chosen to be an open-ended question and after the answers were elicited they were grouped and the above table was drawn. The results are the following: $25.76 \%$ of the students think they will be able to find a suitable job related to the studies undertaken, despite the difficulties they will encounter; $52.27 \%$ of the students think that they will be working as translators and list different institutions they think they may be working with in the future such as publishing houses, foreign embassies in Albania, foreign organizations etc; $4.54 \%$ state they will be working as interpreters with different institutions; $1.52 \%$ think they will be teaching; $2.27 \%$ think they will be doing a job that is not related to their studies; $6.06 \%$ of the students do not know where they will be working after they complete their studies; $1.52 \%$ are thinking of going abroad for further qualifications; $2.27 \%$ think they will be working as translators or interpreters in EU institutions and 3.79\% of the respondents did not answer the question.

Table 15. The job you would like to do after completing the studies.

\begin{tabular}{|c|l|c|c|}
\hline No & The job you would like to do & Absolute value & Percent, \% \\
\hline 1 & Ajob that fits the studies pursued & 33 & 25 \\
\hline 2 & University teacher & 10 & 7.57 \\
\hline 3 & Translator & 64 & 48.48 \\
\hline 4 & Interpreter & 10 & 7.57 \\
\hline 5 & Teacher & 2 & 1.52 \\
\hline 6 & A job that has nothing to do with the studies undertaken & 5 & 3.79 \\
\hline 7 & Go abroad for further qualification & 2 & 1.52 \\
\hline 8 & Translator/Interpreter at EU institutions & 2 & 1.52 \\
\hline 9 & No answer & 4 & 3.03 \\
\hline & Total & 132 & 100 \\
\hline
\end{tabular}

Table 15 provides data collected from the answers to the question of where the students would want to work after completing their course of study. Thus, $48.48 \%$ of the respondents expressed their wish to work as translators; $25 \%$ would want a job related to the studies pursued; $7.57 \%$ would like to have a teaching post at the university; the same percentage even for those wanting to work as interpreters; $3.79 \%$ would prefer a job that is not related to the studies pursued; and lastly, the same percentage $1.52 \%$ belongs to the students who would like to work as foreign language teachers, those who would like to go abroad for further qualifications and those who would like to work as translators or interpreters with EU institutions; 3.03\% of the students failed to answer the question.

\section{Evaluation of the Education Received}

The following table shows the students' opinions in connection with the education received which is in other words the result of joint work between students and professors for the curriculum implementation. It includes rating scale answer choices. 
Table 16. Evaluation of the education received.

\begin{tabular}{|l|l|c|c|c|c|c|c|}
\hline No & Evaluation of the education received & $\begin{array}{c}1 \\
\text { Fully dis- } \\
\text { agree }\end{array}$ & $\begin{array}{c}\mathbf{2} \\
\text { Agree }\end{array}$ & $\begin{array}{c}\mathbf{3} \\
\text { Fully agree }\end{array}$ & \% & N & Mean \\
\hline 1 & $\begin{array}{l}\text { I think the curriculum has helped me } \\
\text { develop personal competencies to be a } \\
\text { good translator. }\end{array}$ & 14.39 & 61.36 & 24.25 & 100 & 132 & 2.09 \\
\hline 2 & $\begin{array}{l}\text { I think the curriculum has helped me } \\
\text { develop personal competencies to be a } \\
\text { good interpreter. }\end{array}$ & 21.97 & 53.03 & 25.00 & 100 & 132 & 2.03 \\
\hline 3 & $\begin{array}{l}\text { I think the curriculum has helped me } \\
\text { develop professional competences to } \\
\text { be a good translator. }\end{array}$ & 26.52 & 59.09 & 14.39 & 100 & 132 & 1.8 \\
\hline 4 & $\begin{array}{l}\text { I think the curriculum has helped me } \\
\text { develop professional competences to } \\
\text { be a good interpreter. }\end{array}$ & 29.54 & 43.94 & 26.52 & 100 & 132 & 1.9 \\
\hline 5 & $\begin{array}{l}\text { I think that the chances to find a job are } \\
\text { better once I finish my studies. }\end{array}$ & 31.82 & 52.27 & 15.91 & 100 & 132 & 1.8 \\
\hline 6 & $\begin{array}{l}\text { I would still choose Translation - Inter- } \\
\text { preting in my second cycle of studies. }\end{array}$ & 12.12 & 36.36 & 51.52 & 100 & 132 & 2.3 \\
\hline
\end{tabular}

The results yielded in connection with the evaluation of the education received show that students do not think they have good job opportunities upon completion of their studies (1.8 mean rating). The extent to which the study program has helped the students develop professional skills to be a good translator or interpreter was also ranked low by them, 1.8 and 1.9 mean rating, respectively, while as regards the extent to which the study program has helped the students develop personal skills to be a good translator or interpreter the students gave a good evaluation, 2.09 and 2.03 mean rating. Despite these evaluations it must be noted that, generally speaking, the students' evaluation of the curriculum is positive as they state that they would make the same choice of studies if they could start anew (2.3 mean rating). As a matter of fact, only $12.12 \%$ of the students consider the studies pursued as non-satisfactory.

\section{Discussion}

The study outlined the identity of the student pursuing Translation - Interpreting studies in the 2-year cycle of studies at the Faculty of Foreign Languages, University of Tirana. Based on the data gathered in connection with the respondent students' age it was concluded that the majority of the students enrolled in the Master program immediately after the 3-year program at the university. A small percentage of the students had finished the 4-year program (the old system of higher education in Albania). Due to a lack of a specific provision in the law on Higher Education concerning their university degree, these students return to university to complete their education with the second cycle studies. The data referring to the respondents' gender are in compliance with the traditional tendency of foreign language careers. As in other European countries, the majority of the students undertaking these studies are females compared to a small percentage of male students.

What is noticed is the fact that all the students are Foreign Languages Faculty graduates of the University of Tirana or other district universities, because the Translation - Interpreting Master program is offered only to students who have received a foreign language education, unlike the Translation - Interpreting Master programs organised in other European countries 
PROBLEMS

OF EDUCATION

IN THE $21^{\text {st }}$ CENTURY

Volume 43, 2012

82

where everyone can enrol as long as they have completed a first cycle study program and have very good knowledge of 3 foreign languages. This has led to a failure so far in our country to apply the preselection process for candidates (Kumbaro 2010). The admission criterion set is the grade point average in the first cycle studies and not a language test on the knowledge of 3 languages the students possess which is the criterion applied in similar Master programs in the world.

A number of respondent students stated that their stay or the language course taken in the language B country has helped them build prior background knowledge, but no student has been given this opportunity in the framework of student mobility promoted by the Bologna process. As regards their work experiences approximately $1 / 4$ of the respondent students said they had worked or still work as foreign language teachers or translators which is a positive thing.

The sample of students shows a community which a priori can be considered highly motivated since for the majority of them Translation - Interpreting was their first and only choice, although $1 / 3$ of the students state that they received no adequate orientation from the faculty at the moment they had to choose their study program for their second cycle studies.

Lack of proper orientation of students could be considered one of the biggest curricular shortcomings. The orientation that the students need to be provided with before they decide which career to undertake is extremely important for making the right decision. Approximately $40 \%$ of the students say that they have had no adequate orientation concerning the translator and interpreter's profession. Even of the students stating that they have received proper orientation about these professions only $7.5 \%$ of them received information about the subjects to be covered by the program which in itself is the essential information a student needs to have to create a clear idea about the course he is going to take and the opportunities this course can offer him for his future career. The majority of the students have received information only about the criteria to be met in order to be admitted to the Translation - Interpreting study program, which is considered superficial information, administrative rather than practical.

Among other sources of information the students mentioned the internet which can not be considered very reliable and truly orientating. Friends and family have contributed by providing some of the students with information. This information remains questionable since it is based on personal impressions. It must be noted that the information provided by the faculty itself is the most important and could be said to provide the proper orientation a student needs.

Relevant to the professional orientation is also a negative fact which needs to be mentioned and that is the fact that half the respondent students stated that they lacked proper information about the subjects to be undertaken before they started the study program, they did not know what the job opportunities would be with the qualification received, the payment they would likely receive in the future etc. The situation grows worse due to the fact that even after 1 or 2 years of studying there (depending on the year they are in) approximately $50 \%$ of the students still lack information about their profession even though they are halfway through or nearing the end of their studies.

Among the main motivations behind the students' decision to undertake this study program is definitely the fact that they like foreign languages. However, other motivations are important too. Thus, a high percentage of students express their interest in travelling and this is related to the concept they have of foreign languages as bridges connecting different lifestyle. What is noticed is also the tendency to multiculturalism since approximately $30 \%$ of the students say that they enjoy meeting people from other countries. However, the main factor driving them to take the decision was the fact that they were told that the job prospects look very good. For a country like Albania with employment problems it is understandable why this factor is the decisive factor when taking a decision about one's study program. It is also important to note that approximately $1 / 3$ of the respondents were driven by dislike of the other study programs offered. 
As regards employment opportunities, which seems to be the Achilles' heel for every $\mid$\begin{tabular}{l} 
PROBLEMS \\
OF EDUCATION \\
IN THE $21^{\text {st }}$ CENTURY \\
Volume 43, 2012 \\
\hline 83
\end{tabular} curriculum, it is obvious that the respondent students identify the opportunities with their wishes. $1 / 3$ of the students are pessimistic about their chances of finding a job that is related to the studies they have pursued. More than half of them would want to and think that they will work as translators. Only few of them consider interpreting as their future employment, because, as some students claim, interpreting is more difficult than translating.

Concerning the students' evaluation of the curriculum, it is worth mentioning that they think that the curriculum has helped them more with the development of personal competences rather than professional ones to become a good translator or interpreter. As concerns the employment opportunities upon completion of the study program approximately $1 / 3$ of the students are pessimistic.

Despite everything, very few students consider these studies as unsatisfactory and the majority of them would make the same choice again.

\section{Conclusions}

This study points to a student who, despite the great motivation and due to the lack of proper orientation to the profession and career, emerges pessimistic about the employment possibilities in the future at a time when the education received should have this particular purpose: to serve the students' future development.

Based on this it is concluded that the outcomes of the curriculum process in the Albanian higher education system are a result of complex balances of academic power rather than a result of in-depth analysis of the needs of the society which this higher education institution claims to serve.

To conclude, the following are recommended:

Improving the contact and information channels between students and the institution. Thus the faculty may set certain days as information and orientation days in which students are provided with the information they need. This information day could be organized as open sessions where all the candidates wishing to apply may ask questions and get answers about the study program they wish to follow. Even a guide of the curricula of the 2-year Master programs, which is missing in the faculty would help the student in this aspect.

Establishing the traditional selection criteria (language test) for the Translation Interpreting study program and in this way opening the doors to all those students who are not necessarily foreign language graduates.

Promote the student mobility, because the Bologna system provides for it.

Analysing the contexts and overcoming the barriers formed by traditional disciplines. This would serve to generate more flexible and more integrated curricular contexts and also to regard Translation- Interpreting disciplines in an innovative way. A considerable number of students who do not wish to work as translators or interpreters, but like foreign languages and have chosen this study program for lack of other interesting study programs offered by the faculty. Thus the Translation- Interpreting Master program fails to meet these students' expectations. Neither does it fully meet the market demands (there are no jobs for all the postgraduates). In order to properly meet these demands and to avoid the oversaturation of the market or even a crisis in the academic demand for Translation- Interpreting it is necessary that the faculty offers a greater variety of study titles. 
PROBLEMS

OF EDUCATION

IN THE $21^{\text {st }}$ CENTURY

Volume 43,2012

\section{References}

BFUG (2004). Report on a Framework for Qualifications of the EHEA. Available at: http:/ /www. jointquality.nl/content/ierland/draft_report_qualification_framework_EHEA2.pdf.

Bolívar, A. (1999). El currículum como un ámbito de estudio. At Escudero, J. M. (Ed.) Diseño, desarrollo e innovación del currículum. Madrid: Universitas.

Bolívar, A. (2008). La práctica curricular. At De La Herrán Gascón, A \& Paredes Labra, J. (Coords.). Didáctica general: la práctica de la enseñanza en Educación Infantil, Primaria y Secundaria. Madrid: McGraw-Hill. 73-87.

Brennan, J., \& Williams, R. (2004). Collecting and using student feedback: a guide to good practice. Higher Education Funding Council for England (HEFCE), Learning and Teaching Support Network (LTSN), Centre for Higher Education Research and Information (CHERI). Available at: http:/ /www.hefce.ac.uk/pubs/rdreports/2003/rd08_03/.

Comisión de las Comunidades Europeas (1995). Libro Blanco sobre la educación y la formación. Enseñar a aprender. Hacía la sociedad cognitive. Brussel. Available at: http:/ /www.uhu.es/ cine.education/didactica/1libroblanco.htm.

Diaz Barriga, A. (2003). El currículo. Tensiones conceptuales y prácticas. REDIE: Revista Electrónica de Investigación Educativa, 5 (2). Available at: http://redie.uabc.mx/contenido/vol5no2/contenidodiazbarriga.pdf.

Fakulteti i Gjuhëve të Huaja, (2005). Kurrikulat sipas Bolonjës. Paketa e informacionit 2005-2006. Tiranë.

Fink, A. (1995). How to ask survey questions. Thousand Oaks: SAGE.

Flinders, D. J., \& Thornon, S. J. (2004). The curriculum study reader. New York: Routledge.

García Pasqual, E. (2004). Didáctica y Currículum: claves para el análisis del proceso de enseñanza. Zaragoza: Mira editorial.

Grotjahn, R. (1987). On the Methodological Basis of Introspective Methods. At Faerch, C. \& Kasper, G. (Eds.), Introspection in second language research. Bristol: Multilingual Matters.

Kearns, J. (2006). Curriculum Renewal in Translator Training: vocational challenges in academic environments with reference to needs and situation analysis and skills transferability from the contemporary experience of Polish translator training culture. $\mathrm{PhD}$ thesis, under direction of Dr. Heinz Lechleiter. Dublin: Dublin City University.

Kumar, R. (1999). Research Methodology. A Step-by-Step Guide for Beginners. Melbourne: Longman.

Kumbaro, M. (2010). Metodologji dhe didaktikë e përkthimit me gojë. Tiranë: shblu.

Li, D. (2002). Translator Training: What Translation Students Have to Say. Meta, 47 (4), 513-531. Available at: http:/ /www.erudit.org/revue/meta/2002/v47/008034ar.pdf.

Nord, C. (2005a). Training Functional Translators. At Tennent, M and others. (Eds.) Training Translators for the New Millenium. Amsterdam-Philadelphia: John Banjamins, 209-223.

Nunan, D. (1992). Research Methods in Language Learning. Cambridge: Cambridge University Press.

Oppenheim, A. N. (1992). Questionnaire design, interviewing and attitude measurement. London: Pinter Publishers.

Schwab, J. (1969). The Practical: A Language for Curriculum. School Review. N. 78. 1-23. Chicago: University of Chicago Press.

Stenhouse, L. (1970). Some Limitations of the use of objectives in curriculum research and planning. Pedagogica Europea, 4, 73-83. Oxford: Blackwell. Available at: http://research.edu.uea.ac.uk/ files/Stenhouse-1970-some Limitations of the use of the objectives.pdf.

UNESCO (1998). Declaración Mundial sobre la Educación Superior en el Siglo XXI. Visión y acción. Conferencia Mundial sobre Educación Superior. Paris: UNESCO. Available at: http:/ /www. unesco.org/education/educprog/wche/declaration_spa.htm 
Mirela PAPA, Alma HAFIZI. Improving the Translation-Interpreting Curriculum through Acknowledging the Educational Needs of Albanian Students

PROBLEMS

OF EDUCATION

IN THE $21^{\text {st }}$ CENTURY

Volume 43, 2012

85

Advised by Irena Lama, University of Tirana, Albania

Received: May 04, 2012

Accepted: June 15, 2012

Mirela Papa

PhD., Professor, University of Tirana, Faculty of Foreign Languages, Italian Department, Blv. Gjergj Fishta, Nd. 138, H. 45, Ap. 12, Tirana, Albania.

E-mail: papamirela@yahoo.com

Alma Hafizi

$\mathrm{PhD}$, Professor of Italian Literature, Translation \& Didactics Literature, University of Shkodra, Faculty of Foreign Languages, Italian Department, Shkodra, Albania.

E-mail: almahafizi@yahoo.it

Website: http//www.unishk.edu.al 